\title{
The Difference between Jurassic and Cretaceous Cherts in Central Europe and Its Heat Treatment before Stone Chip-Ping (Pilot Study)
}

\author{
Petr Schnabl1, Martin Monik², Zdenka Nerudova ${ }^{3}$, David Milde ${ }^{4}$, Simon Kdyr ${ }^{1}$ \\ ${ }^{1}$ Institute of Geology, Czech Academy of Sciences, Prague, Czech Republic \\ ${ }^{2}$ Department of Geology, Faculty of Science, Palacký University, Olomouc, Czech Republic \\ ${ }^{3}$ Centre for Cultural Anthropology, Moravian Museum, Brno, Czech Republic \\ ${ }^{4}$ Department of Inorganic Chemistry, Palacký University, Olomouc, Czech Republic \\ Email: schnabl@gli.cas.cz,martin.monik@gmail.com, znerudova@mzm.cz,david.milde@upol.cz,kdyr@gli.cas.cz
}

How to cite this paper: Schnabl, P., Monik, M., Nerudova, Z., Milde, D. and Kdyr, S. (2019) The Difference between Jurassic and Cretaceous Cherts in Central Europe and Its Heat Treatment before Stone Chip-Ping (Pilot Study). Open Journal of Geology, 9, 674-676.

https://doi.org/10.4236/ojg.2019.910072

Received: August 17, 2019

Accepted: September 22, 2019

Published: September 25, 2019

Copyright $\odot 2019$ by author(s) and Scientific Research Publishing Inc. This work is licensed under the Creative Commons Attribution International License (CC BY 4.0).

http://creativecommons.org/licenses/by/4.0/

\begin{abstract}
Rock-magnetic methods prove that the cultures in Moravia (Europe) 15,000 11,500 years ago might know the technique how to enhance knapping properties of Jurassic chert and Cretaceous flint in order to make stone tools.
\end{abstract}

\section{Keywords}

Jurassic, Cretaceous, Magdalenian, Chert, Flint Artifacts, IRM Aquistion

\section{Introduction}

The Olomučany chert outcrops are located NNE of Brno in a relic of Jurassic sediments in the vicinity of Olomučany village. The layered chert intercalates in Callovian-Kimmeridgian limestones [1]. The chert has dark grey color and microscopically is formed by microfossils and opaque material partly by organic origin. The opaque material is colored rusty-brown due to the presence of iron oxides. Sponge spicules and bryozoans dominate the microfossils. The transparent material is formed by chalcedony and scarce crystals of macro quartz. The chalcedony forms the $0.2 \mathrm{~mm}$ spherulites and cryptocrystalline matrix. The spherulites are probably replaced microfossils [2]. The coarser grain size is typical for Olomučany chert that helps to macroscopically recognize from erratic flints encountered in Silesian and North-Moravian territory. A rare component of the Olomučany chert is glauconitic grains. A healed fissure acts as planes of 
weakness during flint-knapping of the chert. However, a heat-treatment of the rock improves the flaking properties.

The majority of flintstone sources at the North Moravia lies north of Nový Jičín towards the border of the Czech Republic and continues to Poland. The southernmost sediments that were probably used in Magdalenian era were transported during the Saale glaciation [3]. The flint is derived from Scandinavian chalk sediments of Maastrichtian to Danian age. The Campanian flints were not detected in the area. The macroscopic observation shows milky-white, yellow, brown, reddish-brown or grey colors with glossy luster. The microscopic investigation proves mostly pelagic origin with micritic primary texture. The Daanian flints are rich in Briozoas, while Mastrichtian flints are richer in remnants of shells, brachiopods and echinoderms [4].

Heat-treatment of cherts and flints expands flaking quality and edge sharpness. This technique was used by prehistoric people throughout the world. Its oldest evidence in Europe comes from 24 to 17 thousand years old Solutrean archaeological sites at France and Iberian Peninsula. The following gap in using the technique took more than 6 thousand years before it was used in the Mesolithic around 9500 years BP.

\section{Methods}

Similar technique could be identified in the Magdalenian (15,000 - 11,500 uncal BP) of Moravia (Czech Republic) where local Jurassic chert (Olomučany type) was used. Combination the Fourier-transform infrared spectroscopy (FTIR), mass magnetic susceptibility (MSmass) and measurement of isothermal remanent magnetism (IRM). FTIR is suitable to identify heat-treated chert above $300^{\circ} \mathrm{C}$. However, temperatures around $250^{\circ} \mathrm{C}$, are usually sufficient to improve flaking qualities of fine-grained quarzitic materials [5] [6].

\section{Results}

The magnetic properties of flint in natural state are caused predominantly by magnetite, that is hydrated and oxidized during heat treatment. Majority of flints in the cave Balcarka contain also mainly magnetite, and only one contains also mineral with higher coercivity according to the Kruiver et al. [7] method is Goethite.

The iron oxide content of Olomucany chert is much more heterogeneous. The magnetic properties show mixture of magnetite and hematite. The pilot measurement shows that hematite is during heating transformed to a mixture of magnetite and goethite.

\section{Discussion}

The results imply that the majority of flint artifacts were not heat-treated before clipping. Olomucany chert artifacts contain more magnetite than the control rock-samples, which could be interpreted as a heat treatment before the knap- 
ping, later non-intentional heating or quarrying different layers for tool making than are exposed today. The pilot results show that the heat treatment method was not used in the Moravian Magdalenian regularly, the method was not absolutely unknown.

FTIR and MS mass methods generally agree with the IRM acquisition method. Magnetic methods are therefore recommended to be applied in order to identify intentional and unintentional past heat-treatment of cherts and flints.

\section{Acknowledgements}

The research was founded by Czech Science Foundation project "Non-destructive determination of heated artifacts in Upper Palaeolithic assemblages", number: 18-02606S. This is a contribution to UNESCO/IUGS/IGCP 679 project.

\section{Conflicts of Interest}

The authors declare no conflicts of interest regarding the publication of this paper.

\section{References}

[1] Kalášek, J. (1963) Legend to Geological Map 1:200 000, M-33-XXIX Brno. Praha (In Czech)

[2] Přichystal, A. (2013) Lithic raw materials in prehistoric times. Brno.

[3] Macoun, J., Šibrava, V., Tyráček, J. and Kneblová-Vodičková, V. (1965) Kvartér Ostravska a Moravské brány. Ústředníústav geologický, Praha, 1-419.

[4] Brandl, M., Martinez, M.M., Hauzenberger, C., Filzmoser, P., Nymoen, P. and Mehler, N. (2018) A Multi-Technique Analytical Approach to Sourcing Scandinavian Flint: Provenance of Ballast Flint from the Shipwreck "Leirvigen 1", Norway. PLoS ONE, 13, e0200647. https://doi.org/10.1371/journal.pone.0200647

[5] Crabtree, D. and Butler, B. (1964) Notes on Experiments in Flintknapping: 1. Heat Treatment of Silica Materials. Tebiwa, 7, 1-6.

[6] Schmidt, P., Masse, S., Laurent, G., Slodczyk, A., Le Bourhis, E., Perrenoud, C., Livage, J. and Fröhlich, F. (2012) Crystallographic and Structural Transformations of Sedimentary Chalcedony in Flint upon Heat Treatment. Journal of Archaeological Science, 39, 135-144. https://doi.org/10.1016/j.jas.2011.09.012

[7] Kruiver, P.P., Dekkers, M.J. and Heslop, D. (2001) Quantification of Magnetic Coercivity Components by the Analysis of Acquisition Curves of Isothermal Remanent Magnetisation. Earth and Planetary Science Letters, 189, 269-276. https://doi.org/10.1016/S0012-821X(01)00367-3 